\title{
KETERKAITAN POLA BELAJAR SISWA KELAS 6 SD DENGAN NEM YANG DIPEROLEH
}

\author{
Asmadi Alsa dan Purba Hardjito \\ Universitas Gadjah Mada
}

\begin{abstract}
INTISARI
Tujuan penelitian ini adalah untuk mengetahui pengaruh pola belajar yang digunakan siswa kelas 6 sekolah dasar terhadap perolehan Nilai Eblanas Murni (NEM) pada Evaluasi Belajar Tahap Akhir Nasional (EBT ANAS) mereka.

Cara penelilian adalah dengan mengambil sebaryak enam kelas (239 siswa kelas satu) pada tiga SMP Negeri di Kotamadya Yogyakarta. Subyek diminta mengisi angket pola belajar sewaktu mereka duduk of kelas 6 sekolah dasar.

Hasil penelitiannya adalah sebagai berikut: Tidak ada keterkaitan antara pola belajar yang digunakan oleh siswa kelas 6 sekolah dasar dengan NEM yang diperoleh. Faktor inteligensi nampaknya lebih dominan pengaruhnya terhadap tinggi-rendahnya perolehan NEM siswa, dan diperoleh indikasi bahwa proses mengajar-belajar pada siswa kelas 6 sekolah dasar of Kolamadya Yogyakarta dapat memberi bekal pada siswanya untuk menghadapi EBT ANAS sepanjang siswa aktif mengikuti proses belajar of kelas dan mengerjakan tugas-tugas PR yang diberikan guru secara tertib.
\end{abstract}

Kata Kunc i: Pola belajar, NEM, Inteligensi

\section{PENDAHULUAN}

$\mathbf{P}$ restasi belajar siswa yang tinggi menjadi harapan bagi semua fihak. Bagi Bagi sekolah tingginya prestasi yang dapat diraih siswa akan menggembirakan para pendidik, karena hal tersebut merupakan indikator efektivitas dan produktivitas proses mengajar-belajar di kelas, dan tingginya prestasi siswa tersebut sekaligus juga mengangkat citra sekolah. Bagi orangtua, prestasi belajar anak yang tinggi merupakan suatu kebanggaan dan rasa tidak sia-sia dalam usaha membimbing dan mengarahkan anak-anak mereka dalam kegiatan belajar. Bagi siswa sendiri, tingginya prestasi yang diraih dapat memberikan dampak psikologis yang positif, seperti meningkatnya rasa percaya diri, motif berprestasi, dan tingkat aspirasinya. Kalau prestasi yang tinggi berlanjut sampai dengan akhir tahun ajaran, dengan mencapai Nilai Ebtanas Murni (NEM) yang tinggi, hal ini akan menggembirakan baik bagi orangtua. guru, maupun siswa yang bersangkutan. karena akan memudahkan bagi siswa 
tersebut melanjutkan pendidikan ke jenjang yang lebih tinggi, yang akhirnya berakumulasi sampai ia berhasil menjadi seorang sarjana dengan predikat kelulusan yang memuaskan.

Sayangnya, apa yang menjadi harapan banyak fihak tersebut tidak selalu dapat menjadi kenyataan. Banyak di antara siswa mengalami under achiever, yang memiliki prestasi belajar yang rendah. Mengapa itu terjadi?, mengapa prestasi belajar sebagian siswa belum sesuai dengan harapan?". Secara teoretik banyak faktor yang mempengaruhi proses dan hasil belajar siswa. Rendahnya prestasi belajar siswa, selain disebabkan keterbatasan kemampuan intelektual (inteligensi) yang dimiliki siswa, banyak pula disebabkan faktor-faktor lain seperti tidak adanya bimbingan dan pengarahan dari pendidik atau orangtua, lingkungan belajar yang tidak kondusif, atau karena kurangnya usaha dari siswa sendiri.

Penelitan ini memfokuskan pada faktor usaha siswa dalam belajar, yang termanifestasikan dalam pola belajar yang dipakai; sedangkan faktor inteligensi akan dikontrol pengaruhnya. Oleh karena itu pertanyaan penelitian yang diajukan adalah: "Apakah pola belajar yang dipakai siswa kelas 6 sekolah dasar berpengaruh terhadap tinggi-rendahnya Nilai Ebtanas Murni yang mereka peroleh pada Evaluasi BelajarTahaf Akhir Nasional (EBTANAS)?"

Penelitian mengenai prestasi belajar atau Nilai Ebtanas Murni (NEM) sudah banyak dilakukan, seperti hubungan antara inteligensi dengan NEM, keterkaitan antara NEM SMU dengan Prestasi di Perguruan Tinggi, atau perbedaan NEM yang diperoleh antara siswa dan siswi, tetapi belum pernah ada peneliti sebelumnya yang mengkaji tentang keterkaitan antara pola belajar dengan NEM yang diperoleh siswa kelas 6 sekolah dasar. Oleh karena itu tema ini dipilih untuk diteliti karena orisinalitasnya.
Penelitian ini bertujuan untuk menguji secara empirik tentang ada-tidaknya keterkaitan atau hubungan antara:

a. Rutinitas belajar siswa kelas 6 SD dengan NEM yang diperoleh pada EBTANAS

b. Rehearsal (pengulangan) pelajaran dengan NEM yang diperoleh pada EBTANAS

c. Keikutsertaan les dengan NEM yang diperoleh pada EBTANAS

d. Jumlah jam belajar dengan NEM yang diperoleh pada EBTANAS

e. Pengatasan kesulitan belajar dengan NEM yang diperoleh pada EBTANAS

\section{DASAR TEORI}

Prestasi belajar adalah has il belajar yang diperoleh siswa selama periode waktu tertentu, yang dinyatakan dalam simbol huruf atau bilangan, seperti yang tercantum dalam rapot atau Nilai Ebtanas Murni (Wirawan, 1976). Nilai Ebtanas Murni (NEM) merupakan prestasi belajar siswa kelas akhir yang diperoleh siswa dari hasil evaluasi belajar tahaf akhir secara nasional, yang dinyatakan dalam bentuk bilangan.

Prestasi belajar (dalam konteks penelitian ini adalah Nilai Ebtanas Murni) dipengaruhi oleh banyak faktor. Sorenson (1964) menyebutkan faktor-faktor itu adalah inteligensi, kondisi fisik dan psikis anak. kemampuan belajar, sikap anak terhadap guru dan pelajaran, dan bimbingan belajar yang diterima anak. Menu nut Kolesnik (1970) pola belajar siswa akan mempengaruhi pula keberhasilan anak dalam belajar. Walgito (1989) menyebut faktor-faktor yang mempengaruhi belajar siswa adalah faktor individu siswa, lingkungan, instrumen, dan bahan yang dipelajari.

Berdasar pendapat-pendapat di atas. peneliti mengelompokkan faktor-faktor yang mempengaruhi belajar menjadi empat. yaitu 
faktor internal, faktor eksternal, faktor instrumental, dan faktor strategi dalam belajar. Faktor internal meliputi semua kondisi fisik dan kondisi mental-psikologis siswa, faktor eksternal meliputi lingkungan fisik dan sosial-psikologis, faktor instrumentail meliputi perangkat keras dan perangkat lunak yang diperlukan dalam belajar, dan faktor strategi dalam belajar.

Bentuk strategi belajar terlihat dalam pola-pola belajar yang digunakan siswa, seperti rutinitas belajar, rehear salterhadap pelajaran, keikutsertaan dalam les, jumlah jam belajar, dan usaha mengatasi kesukaran belajar. Pola-pola belajartersebut di atas semakin sering nampak dalam perilaku belajar siswa saat siswa akan mienghadapi ujian akhir atau menghadapi evaluasi belajar tahap akhir. Diasumsikan bahwa pola-pola belajar tersebut berpengaruh terhadap keberhasilan belajar siswa. Seperti dikatakan oleh Eggen dan Kauchak (1997) bahwa pengelolaan belajar yang efektif akan menghasilkan belajar yang efektif pula. Stein, dkk. (dikutip Slavin, 1991) mengatakan bahwa latihan-latihan efektif, penggunaan waktu belajar yang cukup, dan sering mengerjakan tugas-tugas atau PR, akan meningkatkan hasil belajar.

Ada dua kelompok teori besar yang menerangkan perilaku individu dalam belajar. Kelompok pertama, yaitu kelompok teori behavioral, menerangkan bahwa belajar akan mendapatkan hasil yang baik apabila indivdu sering mengulang (melakukan rehearsal), latihan, menerapkan. menggunakan, dan membiasakan dengan apa yang sedang dipelajari. Ungkapan-ungkapan seperti practice makes perfect, experience is the best teacher, trial and error learning. bersumber dari kelompok teori belajar behavioral. Thorndike, salah satu dari banyak tokoh kelompok teori ini, mengemukakan antara lain dua hukum belajar yaitu the law of exercise dan the law of readiness.
Hukum yang pertama menjelaskan bahwa semakin banyak siswa melakukan latihan dan menggunakan bahan yang sedang dipelajarinya, maka semakin baik penguasaannya terhadap bahan tersebut. Hukum yang kedua menyebutkan bahwa didalam belajar siswa harus dalam keadaan siap untuk menghadapi pelajarannya. Keadaan siap di sini meliputi bukan hanya aspek-aspek yang diperlukan untuk belajar sudah matureatau anak sudah sampai pada masa pekanya, akan tetapi juga siap secara fisik dan psikis.

Tokoh lainnya dan kelompok teori behavioralini, yaitu Pavlov, mengatakan bahwa belajar adalah "pembiasaan" (conditioning). Artinya semakin sering seorang siswa "bergelut" dengan materi pelajaran yang sedang ia pelajari, maka semakin baik pemahamannya terhadap materi pelajaran tersebut. Slavin (1991) mengatakan bahwa pengulangan secara mentaf terhadap bahan pelajaran akan meningkatkan retensi. Lebih tegas dikatakan oleh Sorenson (1964) bahwa retensi akan setalu meningkat apabila subyek mengulang bahan pelajaran yang sudah dipelajari sebelumnya. Selaras dengan kedua pendapat di atas, Marx (1976) mengatakan bahwa pengulangan (rehearsa) terhadap bahan pelajaran perlu dilakukan agar informasi yang masuk dalam memori jangka pendek (short-term memory) dapa: dipertahankan dan dapat masuk ke dalam ingatan jangka panjang (long-term memory); sehingga retensi terhadap bahan pelajaran yang dipelajari semakin baik. Penelitian yang dilakukan oleh Knueger (dikutip Zimbardodan Ruch, 1980) mendapatkan hasil bahwa kelompok subyek yang mengulangi bahan yang dipelajari sebelumnya, dapat mengingat bahan dua kali lipat lebih banyak dari kelompok subyek yang tidak mengulangi bahan.

Kelompok teori yang kedua adalah kelompok teon kognitif. Kelompok teon in: 
mengatakan bahwa hasil belajar tidak akan baik apabila subyek hanya belajar sepotongsepotong dari suatu konsep yang dipelajari. Pemahaman hanya terhadap bagian-bagian tertentu dari suatu keseluruhan materi atau kosep yang dipelajari tidak akan menimbulkan pengertian. Insightfulleaming adalah kunci belajar menurut kelompok teori ini. Oleh sebab itu siswa yang belum menguasai sepenuhnya atau tidak mengerti tentang materi pelajaran yang sedang dipelajari, ia harus berusaha secara aktif untuk mendapatkan jawabannya, bertanya dengan guru, teman, atau orangtuanya, atau membaca dari sumber atau buku lain. Menurut teori ini, umumnya anak akan termotivasi dan akan bertanya tentang hal yang ia belum tahu, karena ketidaktahuan akan menjadikan kondisi anak dalam keadaan disequilibrium.

\section{HIPOTESIS}

Berdasar landasan teori di atas. maka hipotesis penelitian yang diajukan dan akan diuji kebenarannya adalah:

1. Kelompok siswa yang rutin dalam belajar memperoleh NEM yang lebih tinggi daripada kelompok siswa yang tidak rutin dalam belajar.

2. Semakin banyak jumlah jam belajar yang digunakan siswa kelas 6 SD maka semakin tinggi NEM yang dicapai.

3. Kelompok siswa yang mengikuti les pelajaran memperoleh NEM yang lebih tinggi daripada kelompok siswa yang tidak mengikuti ies.

4. Kelompok siswa yang berusaha mengatasi kesukaran dalam belajar dengan bertanya memilki rata-rata NEM yang lebih tinggi daripada kelompok siswa yang tidak bertanya ketika mengalami kesukaran dalam belajar.

5. Kelompok siswa yang melakukan rehear sal(mengulang pelajaran) memiliki rata-rata NEM yang lebihtinggi daripada kelompok siswa yang tidak melakukan rehearsal

6. Kefompok siswa yang belajar dari buku lain selain yang diperoleh dari guru memiliki rata-rata NEM yang lebih tinggi daripada kelompok siswa yang hanya belajar dari bahan yang diperoleh dari guru di sekolah.

7. Kelompok siswa yang selalu mengerjakan PR memperoleh rata-rata NEM yang lebih tinggi daripada kelompok siswa yang hanya kadang-kadang mengerjakan PR dan kelompok siswa yang tidak pernah mengerjakan PR.

\section{METODE}

\section{Subjek}

Subyek penelitian adalah siswa kelas 1 , yang baru satu bulan menjadi siswa SMP Negeri 1 Yogyakarta, SMP Negeri 6 Yogyakarta, dan SMP Negeri 8 Yogyakarta. Masing-masing SMP diambil dua kelas, keseluruhan subyek penelitiannya sebanyak 239 siswa. Pada hari pertama pelaksanaan penelitian semua subyek diberi tes interigensi SPM, dan pada hari kedua mereka diminta untuk mengisi angket pola belajar. Pada hari kedua ini juga diambil data NEM SD masing-masing subyek penelitian dari dokumentasi yang ada di masingmasing SMP, Setelah dilakukan skoring terhadap hasil tes inteligensi SPM dan angket pola belajar, maka data dari ketiga variabel penelitian dianalisis.

\section{Prosedur}

Penelitian ini melibatkan tiga variabel penelitian yaitu Nilai Ebtanas Murni (NEM), inteligensi, dan Pola Belajar. Nilai Ebtanas Murni adalah skor atau nilai yang diperoleh siswa dalam mengikuti evaluasi belajartahaf 
akhir tingkat nasional. Inteligensi adakah taraf kecerdasan umum siswa, sedangkan Pola Belajar adalah penerapan strategi belajar yang dipakai siswa dalam belajar selama duduk di kelas 6 sekolah dasar, yang meliputi rutinitas belajar, rata-rata jumlah jam belajar perhari, les pelajaran, bertanya ketika mengalami kesulitan dalam belajar, melakukan rehearsal atau pengulangan belajar, sumber bahan dalam belajar, dan pengerjaan $\mathrm{PA}$.

\section{Alat Pengumpuian Dak}

Alat yang dipakai dalam penelitian ini adalah angket, tes inteligensi Standard Progressive Matrices, dan dokumentasi. Angket dimaksudkan untuk mengungkap pola belajar siswa, Standard Progressive Matrices untuk mengungkap taraf inteligensi. umum, dan dokumentasi untuk mengetahui NEM yang diperoleh siswa. Data variabel pola belajar siswa yang diperoleh dari angket diasumsikan valid karena butir-butir angketnya mengungkap fakta obyektif, dan mudah dipahami maksudnya oleh siswa kelas 6 SD karena dirumuskan dengan kalimat yang sederhana. Data inteligensi siswa yang diperoleh dari tes inteligensi Standard Progressive Matrices dipandang valid karena SPM untuk mengukur inteligensi telah terbukti validitasnya. Data Nilai Ebtanas Murni diasumsikan memenuhi content validity sebagai achievement test, mengingat Ebtanas merupakan satusatunya alat evaluasi hasil belajar tahap akhir secara nasional.

\section{Cara Analisis}

Untuk menguji hipotesis penelitian, data yang sudah diperoleh dianalisis secara kuantitatif dengan menggunakan teknik. statistik. Teknik statistik yang dipakai untuk. menguji ketujuh hipotesis yang diajukan adalah "Analisis Kovariansi Satu Jalur" dengan satu kovariabel. Selain itu dilakukan analisis tambahan dengan menggunakan teknik korelasi product moment untuk mengetahui korelasi antara inteligensi dan NEM. serta analisis variansi satu jalur untuk. mengetahui perbedaan inteligensi dan perbedaan NEM antara siswa yang berasal dari tiga SMP Negeri yang berbeda.

\section{HASIL PENELITIAN}

Has i analisis data menunjukkan bahwa (1) Tidakada perbedaan rala-rata NEMyang diperoleh antara siswa yang belajarsecara rutin dan siswa yang belajar secara tidak rutin. Kontrol dilakukan terhadap faktor inteligensi. Nilai F perbedaan rata-rata NEM antara siswa yang belajar secara rutin dan siswa yang belajar secara tidak nutin adalah sebesar 0,786 dengan $p>0,05$; (2) Tidak ada pertedaan rata-rata NEM yang diperoleh antara siswa yang selalu mengulang, siswa yang kadang-kadang mengulang, dan siswa yang tidak pernah mengulang pelajaran yang diperoleh di sekolah pada hari yang sama. Kontrol dilakukan terhadap faktor inteligensi. Nilai $F$ perbedaan rata-rata NEM antara siswa yang selaiu mengulang. kadang-kadang mengulang, dan siswa yang tidak pernah mengulang pelajaran yang diperoleh di sekolah pada hari yang sama adalah sebesar 0.736 dengan $p>0,05$; (3) Tidak ada perbedaan rata-rata NEM yang diperoleh antara siswa yang ikut les dan siswa yang tidak ikut les. Kontrol dilakukan terhadap faktor inteligensi. Nilai $F$ perbedaan rata-rata NEM antara siswa yang kut les dan siswa yang tidak ikut les adalah sebesar 0,863 dengan $p>0,053$; (4) Tidak ada perbedaan rata-rata NEM yang diperoleh anlara siswa yang belajar rata-rata lebih dua jam, belajar rata-rata antara 1-2 jam, dan belajar rata-rata kurang dari 1 jam perhari. Kontrol dilakukan terhadap taktor inteligensi, nilai $F$ perbedaan rata-rata NEM antara 
siswa yang belajar rata-rata lebih dua jam, belajar rata-rata antara 1-2 jam, dan belajar rata-rata kurang dari 1 jam perhari adalah sebesar 0,933 dengan $p>0,05$; (5) Tidak ada perbedaan rata-rata NEM yang diperoleh antara siswa yang selalubertanya, kadangkadang bertanya, dan tidak pemah bertanya ketika mengalami kesulitan dalam belajar. Kontrol dilakukan terhadap faktor inteligensi, nilai $F$ pebedaan rata-rata NEM antara siswa yang selalu bertanya, siswa yang kadang-kadang bertanya, dan siswa yang tidak pernah bertanya ketika mengalami kesulitan dalam belajar, adalah sebesar 1,299 dengan $p>0,05$. Ini berarti bahwa

Keterkaitan antara NEM dengan aktivitas pengerjaan PR dan antara NEM dengan sumber bahan yang dipelajari (hipotesis 6 dan 7), tidak dilakukan analisis karena frekunsi subyek pada kategori yang berkaitan dengan kedua variabel bebas tersebut terlału sedikit. Tidak ada seorangpun siswa yanag menjawab "tidak pernah mengejjakan PR" untuk variabel bebas aktivitas mengerjakan PR, dan hanya 12 siswa diantara 239 siswa yang menggunakan sumber bahan pelajaran dari buku-buku lain selain yang diperoleh dari gurunya. Kasus yang pertama menunjukkan bahwa umumnya siswa sekolah dasar di Yogyakarta tidak ada yang mengabaikan tugas mereka dalam mengerjakan PR dari sekolah. Hal yang keoua mengindikasikan bahwa siswa sekolah dasar, sesuai dengan perkembangannya, masih memerlukan bimbingan dan pengarahan dalam belajar. Mereka umumnya belum ada inisiatif untuk mencari sumber informasi pelajaran dari buku lain selain yang diperoleh dari gurunya.

Koefisien korelasi product moment antara variabel inteligensi dan variabel NEM adalah sebesaro, 183 dengan $p<0.01$. Nilai $F$ perbedaan inteligensi antara siswa SMP Negeri 1 Yogyakarta, SMP Negeri 6 Yogyakarta, dan SMP Negeri 8 Yogyakarta adakah sebesar 3,942 dengan $p<0,05$, sedangkan nilai $F$ perbedaan NEM antara ketiga kelompok siswa tersebut adalah 289,258 dengan $p<0,01$.

\section{PEMBAHASAN}

Hasil penelitian yang diperolah tidak sejalan dengan asumsi teoritiknya; atau dengan perkataan lain kelima hipotesis penelitian yang diajukan tidak teruji kebenarannya. Kemungkinan tidak terujinya hipotesis penelitian ini adalah karena adanya faktor yang lebih dominan dalam mempengaruhi tinggi-rendahnya NEM siswa. Faktor tersebut adalah inteligensi.

Berdasarkan analisis data tambahan diketemukan korelasi yang positif dan signifikan antara inteligensi dan NEM. Memperkuat keterkaitan antara inteligensi dan NEM tersebut juga dapat dilihat dari analisis tambahan lainnya bahwa ada perbedaan yang sangat nyata antara tiga sekolah yang diteliti dalam hal inteligensi dan NEM. Masyarakat tahu bahwa penerimaan siswa SMP didasarkan pada tinggi-rendahnya NEM calon siswa.

Secara berturut-turut dari ketiga SMP yang diteliti, yang tertinggi NEMnya adalah SMP Negeri 8 , kemudian disusul SMP Negeri 1, dan SMP Negeri 6. Urutan tersebut juga berlaku untuk variabel inteligensi. Dari hasi analisis data tersebut terdapat indikasi. bahwa siswa yang inteligensinya relatif tinggi dan mengikuti sekolah secara teratur serta selalu mengerjakan PR (dari data yang diperoleh tidak seorangpun siswa yang tidak mengerjakan PR yang diberikan oleh gurunya), sokalipun belajarnya tidak rutin. tidak langsung mengulang pada harl yang sama terhadap pelajaran yang diperoleh di sekolah, tidak mengikuti les, jumlah jam belajarnya perhari rata-rata tidak banyak, dan kurang aktif dalam bertanya, masih mampu untuk memperoleh NEM yang 
tinggi. Dengan perkataan lain bahwa sekolah dasar di Yogyakarta (sebagian besar siswa SMP di Yogyakarta berasal dari SD di Yogyakarta) proses pembelajarannya, dalam hal ini untuk siswa kelas 6, sudah memberikan modal yang cukup bagi siswa untuk memperoleh NEM sesuai dengan tingkat inteligensi setiap siswa, sepanjang siswanya aktif, tertib dan teratur mengikuti proses belajar di kelas dan mengerjakan PR yang diberikan guru.

Kemungkinan lain tidak terujinya hipotesis penelitian adalah karena umumnya siswayang menghadapi EBTANAS akan meningkatkan aktivitas belajarnya beberapa saat saja menjelang EBTANAS, sedangkan butir-butir angket pola belajar yang diberikan kepada siswa adalah pola belajar mereka saat duduk di kelas 6 sekolah dasar.

\section{KESIMPULAN DAN SARAN}

Tidak ada keterkaitan antara pola belajar yang digunakan oleh siswa kelas 6 sekolah dasar dengan NEM yang diperoleh. Rutinitas belajar, pengulangan pelajaran yang diperoleh di sekolah pada hari yang sama, keikutsertaan siswa dalam mengikuti pelajaran tambahan (les), rata-rata jumlah jam belajar yang dihabiskan siswa setiap harinya, dan aktivitas bertanya ketika siswa mengalami kesukaran dalam belajar, kesemuanya tidak membawa pengaruh terhadap tinggi-rendahnya NEM yang diperoleh.

Nampaknya faktor inteligensi lebih dominan pengaruhnya terhadap tinggirendahnya perolehan NEM siswa. Dari hasil tersebut dapat diindikasikan bahwa proses belajar-mengajar pada siswa kelas 6 sekolah dasar di Kotamadya Yogyakarta dapat memberi bekal pada siswanya untuk menghadapi EBTANAS sepanjang siswa aktif mengikuti proses belajar di kelas dan mengerjakan tugas-tugas PR yang diberikan guru secara tertib. Oleh sebab itu disarankan pada sekolah dasar di Kotamadya Yogyakarta yang lulusannya banyak diterima of SMP Negeri 1, 6, dan 8 untuk paling tidak mempertahankan proses belajar-mengajarnya selama ini; dan bagi siswa disarankan untuk selalu mengikuti aktivitas belajar di sekolah dan menger jakan tugas-tugas PR yang diberikan guru.

\section{DAFTAR PUSTAKA}

Eggen, P. dan Kauchak, D., 1997. Educational Psychology. Third-edition. New Jersey. Prentice Hall Inc.

Kolesnik, W.B., 1970. Educational Psychology. New York: McGraw-Hill Book Company.

Marx, M.H., 1976. Introduction to Psychology: Problems, Prosedures, and Principles. New York: Macmillan Publishing $\mathrm{Co}$., Inc.

Slavin, R.E., 1991. Educational Psychology. Third-edition. Englewood Cliffs: Prentice Hall Inc.

Sorenson, H., 1964. Psychology in Educalion. New Delhi: Tata McGraw-Hill Publishing $\mathrm{Co}_{0}$. Ltd.

Walgito, B., 1989. Bimbingan dan Penyuluhan Sekolaht. Edisi keempat. Yogyakarta: Andi Offset.

Wirawan, Y.G., 1976. Faktor-Faktor yang Bertalian dengan Perbedaan Antara Prestasi dan Kemampuan Psikologis pada Pelajar SMP di Yogyakarta. Jumal Psikologit. Volume 1, hal. 1-20.

Zimbardo, PG. \& Ruch, F.L., 1980. Essential of Psychology and Life.llinois: Scott, Foresman \& Company.

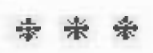


